\title{
The War against Oil Theft in the Niger Delta Region and Advocacy Campaigns by the Nigerian Press: A Normative Appraisal
}

\author{
Godwin B. Okon \\ Correspondence: Godwin B. Okon, Department of Mass Communication, Rivers state University of Science and \\ Technology, PMB 5080, Port Harcourt, Nigeria
}

Received: February 9, 2014 Accepted: February 20, 2014 Available online: April 14, 2014

doi:10.11114/smc.v2i1.341

URL: http://dx.doi.org/10.11114/smc.v2i1.341

\begin{abstract}
With the down turn in the Nigerian economy occasioned by the menace of oil theft in the Niger Delta region, this study sought to analyse how the Nigerian press, through content, stimulated highlights that may help curb the menace. This necessitated content analyses of two newspapers and a magazine. The Guardian and This Day were purposively selected based on the fact that they are foremost national dailies with widespread readership as outlined by the Audit Bureau of Circulation while Tell magazine was selected based on its ideological posture and national spread. The third quarter of 2013 formed the period of study. Thirty-six issues of the newspapers/magazine spread across twelve weeks were selected and studied using a constructed calendar. Inter-coder reliability stood at 0.73 . Findings revealed that the newspapers/magazine studied devoted less than $2 \%$ of their total news space to straight news on the subject matter with about 3\% on features. For the editorial and advertorial spectrum, a lateral $0 \%$ was observed. Deductively, the newspapers/magazine studied did not devote significant space to advocacy. The findings further revealed that the reportage given to the subject matter by the newspapers/magazine was not sufficient to draw attention to the menace of oil theft and its attendant consequences. It was therefore recommended that Nigerian newspapers and magazines should focus content on issues of socio-economic importance. It was further recommended that Nigerian newspapers and magazines should intensify advocacy for proactive policies that will stem the tide of oil theft while paving way for egalitarianism in the Nigerian socio-economic sphere.
\end{abstract}

Keywords: Advocacy, Appraisal, Niger Delta, Normative, Oil theft

\section{Overview}

Nigeria's economy can at best be operationalized as monomorphic being that it is predominantly dependent on revenue from oil exploration and exportation. This has in contemporary times become a bane since efforts at diversifying the economy have yielded negligible gains. The vulnerability of the economy becomes even more glaring when viewed against the backdrop of the reverberating macroeconomic instability that has come to characterise the international oil market. In other words, whenever the international oil market experiences a downturn, the Nigerian economy suffers gloom and conversely blooms whenever the international oil market skyline brightens up.

This is indeed an irony for a country that is blessed with abundant human and natural resources. Between 2003 and 2008, the economy of Nigeria experienced a down turn due to the activities of the Niger Delta militants characterized by pipeline vandalisation, hostage taking, wanton killing and reckless shooting. The activities of the militants made the entire Niger Delta region unsafe for oil exploration and this grossly took its toll on the Nigerian economy.

The Nigeria economy however experienced some reprieve in 2009 when the then president late Umaru Musa Yar'Adua signed a peace pact with the Niger Delta militants through the government's amnesty programme. This programme sought to rehabilitate the militants through a linkage programme of arms for entrepreneurial development. This however saw many militants surrendering their arms to the Federal government with corresponding rewards that ranged from scholarships to intervention grants.

With this peace deal in place, optimal oil exploration activities resumed in the region with spiraling effects that engendered a rebound in the economy. Contemporary events however show that this economic rebound was bereft of sustainability.

At present, the Nigerian economy, as epitomized by oil revenue, is experiencing yet another down turn which this time around is not as a result of the Niger Delta militants but as a result of the activities of oil thieves. These oil thieves 
primarily engage in the illegal sale of crude oil. Their activities are popularly referred to as oil bunkering which according to the statutes of the Federal Republic of Nigeria is a form of "economic sabotage".

It has however been widely reported that illegal oil bunkering and its dependent economic sectors have replaced legitimate economic activities in large parts of the Niger Delta region. In this particular instance, individuals transfer oil extracted illegally from oil facilities, by whatever means, onto barges or containers which then take the oil to tankers. Interestingly, aerial and satellite photography confirm the loading of hundreds of barges with oil each day. This illegal crude is then sold to foreign oil prospectors who operate under false names. Leaders of armed bands arrange internal protection when these illegal activities go on while those who are not linked to armed groups bribe security officials to look the other way during loading of specific barges. (www.elombah.com/index.php/section/30.news/theeconomy/8022-fundamentalsofillegaloilbunkering).

Ameh (2013) notes that "about 400,000 barrels of Nigeria's crude oil are stolen daily" (p.7). The imputation however is that the oil thieves are not 'ghosts' and can be contained if the Federal government demonstrates the political will to do so.

The Ministry of Niger Delta Affairs in collaboration with the office of the special Adviser to the president on Niger Delta Affairs recently held a conference in Lagos. The communiqué issued at the conference urged the Federal government to immediately curb the menace of oil theft and illegal bunkering.

At the opening of the 2013 Nigeria oil and gas exhibition in Abuja, the minister of petroleum, Diezanni Allison-Madueke noted that President Goodluck Jonathan is worried about crude oil theft in the Niger Delta. Consequently, the president has been mandated to explore all machineries at the disposal of his office in checking oil theft in the country.

The menace of oil theft is a scourge that threatens the sovereignty of Nigeria and by extension the wellbeing of its citizenry. It is a war that must be fought by all Nigerians. The media cannot be aloof in this war. The responsibility of the press in the face of the war against oil theft in Nigeria is to light the way and drive for action. The press through content should be able to portray how similar problems were solved in other countries. This invariably can be subsumed within the framework of pointing out needs with a view to proffering solutions.

This is where advocacy journalism comes in. Advocacy journalism according to Wallack (1993) is "an innovative and sophisticated way of critically using the press to promote change because the mass media have become a powerful force in our society. (p.2).

This no doubt requires the identification of an issue and an accompanying initiative to address that issue. The issue in this context is the war against oil theft and the initiative expected of the media is hinged on the simulation and synthesis of highlights that may help curb the menace. How well the Nigerian press has fared in this role prescription is indeed the concern of this study.

\section{The Setting}

The Niger Delta region is situated at the estuary of the River Niger. The region extends over $70,000 \mathrm{~km}^{2}$ and makes up $7.5 \%$ of Nigeria's land mass. The Niger Delta region includes the states of Abia, Akwa- Ibom, Bayelsa, Cross River, Delta, Edo, Imo, Ondo and Rivers. Oil exploration has become, since 1968, the major production activity in the area. It is estimated that more than 2 million barrels of oil are extracted in the Niger Delta region daily thus accounting for more than $75 \%$ of Nigeria's export earnings.

\section{The Problem}

The economy of Nigeria is indeed an irony. With a population of about 170 million people, the country is generously endowed with human, physical and natural resources. The country at present is ranked the sixth largest producer of crude oil and also has the sixth largest gas reserves in the world.

According to Ibru (2013) "the diversification of the economy has become imperative and compelling because the disproportionate reliance on natural resources exposes the economy to tremendous risk of shocks and vulnerability. (Ibru, Goodie-http://www.osundefender.org/7p=125430). It was also reported that there was a shortfall in allocation to the three tiers of government in May and July 2013.

In corroboration however, the World Bank 2013 reports indicate that...declining oil revenues have placed increasing pressures on government budgets. As of the second half of 2013, total federation revenues available for sharing by the three tiers of government fell short of projections by $21 \%$. The balance of the fiscal reserve of the country (Excess Crude Account) declined from over $\$ 9$ billion in early 2013 to $\$ 5$ billion by mid year. The implementation of the capital budget has been adversely affected as only a little over half of the federal capital budget has been made available to 
MDAs as of the end of September, 2013, for the implementation of investment projects. (www.worldbank.org/en/country/nigeria/overview)

The imputation however is that the economy of Nigeria cannot be insulated from the reverberating shocks that impinges on the oil sector. The dwindling oil revenue is as a result of the diversionary oil activities in the Niger Delta region because illegal routing of crude oil portends loss of revenue.

At the first Benson Lulu-Briggs professorial chair round table with the theme "sustaining investments and reserves in the face of growing challenges"; organized by the University of Port Harcourt, Rivers State, an American oil expert and President, Global Water and Energy strategy team (GWEST), Paul Michael Winbey warned that the continual loss of some 400,000 barrels of crude oil to illegal bunkering could undermine the viability of the Nigerian economy. Mr. Winbey further noted that as Nigeria's illicit crude oil business spreads across the world, criminal gangs are on ground to smuggle the product into other economies without payment of necessary duties. (Kelvin Ebiri- How bunkering puts Nigeria's oil export in jeopardy. Sunday, $29^{\text {th }}$ September, 2013,www.ngoguardiannews.com/business-news/13405-how)

This no doubt raises fears and worries since the level of crude oil theft in monetary terms is projected to stand at $\$ 7$ billion. There must be a voice against lawlessness, injustice and corruption. That voice is the voice of the press.

Going by the unhealthy economic indicators emanating as a result of oil theft in the Niger Delta region, the press is expected to call attention to the negative propensities of this trend if left unchecked. The press is also expected to enjoin the government to live up to its responsibilities of safeguarding the common wealth of the nation through constructive criticisms. Furthermore the press is expected to generate ideas through an ideological platform on how this oil theft menace can be curbed. This tripartite spectrum upon which the role of the press is predicated is indeed the conveyor belt of advocacy journalism. By distillation, therefore, has the press so far documented the dynamics and mechanics of oil thieves with a view to creating a platform for ideas generation? Has the press illuminated the dangers of oil theft through interpretative reporting in the form of editorial and features? Has the press engaged advocacy in the form of a clarion call on requisite stakeholders to rise to the occasion? The problem of this study is therefore predicated on the foregoing.

\section{Study Objectives}

In view of the adverse implications of oil theft in the region, it is the concern of this study to;

1) Find out if the Nigerian press has through content adequately enlightened the public on the dynamics of oil bunkering and its attendant consequences on the economy.

2) Find out if the Nigerian press, through interpretative reporting and public service announcements, engages in advocacy campaigns geared towards curbing the menace of oil theft in the Niger Delta.

3) Find out the frequency with which the Nigerian press engages in such advocacy campaigns with a view to ascertaining how well it has lived up to its normative responsibilities.

\section{Research Questions}

1) How well has the Nigerian press through content enlightened the people on the operations of oil thieves and the adverse effects of these operations in the economy?

2) To what extent has the Nigerian press carried out advocacy campaigns on how the activities of oil thieves in the Niger Delta region can be curtailed?

3) To what extent does the Nigerian press accord sustainability to its advocacy campaigns?

\section{Scope}

This study was limited to the press highlights of the third quarter of 2013. In other words, the manifest content of select newspapers including a magazine within the period outlined above were studied.

\section{Operationalization of Terms}

Advocacy-A crusade for probity, justice, transparency and proactive security checks geared towards checking the oil theft menace.

Economy: That sector that ensures the well being of a nation.

Interpretative reporting: Enriching news reports with background details.

Normative: The primary role of the press epitomized through informing, educating and charting a right course of action for the society to follow.

Oil Bunkering: Illegal sale of crude oil. 
Press: Special reference is here made to the print media.

Public service announcements: Advertorials that tend to point out ills in the society with a view to correcting them.

\section{Literature review}

The concept - press - has been aptly described by McQuail (2012) to encompass all "newspapers and magazines, journalists, editors and media owners whose core activities, besides accepting some public responsibilities, revolve around the production and distribution of public information" (p. 60).

From a normative perspective, however, the function of the press among others include: to inform, educate and entertain. When distilled further, the press acts as the watch dog of the society through its activities of seeking out and transmitting information about the society. In this regard Hasan (2013) notes that by so doing, "the divergent views and in-depth analysis of the press on topical issues are of vital importance in the stance the public takes on critical issues" (p. 128).

Through such presentations the press illuminates the social fabric of every society and helps to shape its pattern. In a world where information is power, the availability of information and accessibility to media content becomes a necessary parameter for development.

Rodman (2012) in his narrative notes that the main effect of the press is "telling the people not what to think, but what to think about. In other words, the amount of attention given to an issue in the media affects the level of importance the public assigns to that issue" (p. 44).

The foregoing is clearly linked to the fact that the press ought not to report events alone but should go a step further to offer interpretations to such reports. According to Dominick (2011).

Another example of this function can be found on the editorial pages of a print medium. Interpretation, comment and opinion are provided for the reader as an added perspective on the new stories carried on other pages. Articles that analyze the causes of an event or that discuss the implications of government policies are also examples of the interpretation function. Through this function, the audiences become exposed to a large number of points of view and because of this; a person can evaluate all sides of an issue before arriving at an opinion (p. 33)

This indeed is the beauty of the role of the press in giving an account of the goings on in a society within a context that gives them meaning. It however becomes obvious that closely allied with the surveillance function is the interpretation function of the press which makes available to the individual, a wide range of requisite opinions he or she may not have access to through interpersonal communication.

It is however worthwhile to note that by inference, the press can bring to bear on public opinion, the mechanics of oil theft and its attendant consequences on the economy with a view to stimulating a concerted drive for action to curb the menace.

According to Wallack(1999), Media advocacy is a crucial component of a comprehensive media campaign because it empowers the community and targets policy makers. It is a way of making one's message heard and inspiring others to join create a flood of support (p. 246).

Media advocacy by inference is the strategic use of the media to communicate with large numbers of people to advance a social or public objective or change public attitudes on an important public matter.

In a study on using media and research for advocacy, Efroymson (2006) found that the "mass media are extremely powerful for reaching governments to work for change since government officials watch TV, listen to radio and read newspapers; they understand what issues are hot and need to be addressed as well as offer information on problems and solutions that otherwise might be ignored" (p.6)

The imputation however is that the more an issue is reported in the news, the more people will be aware of and concerned about it, and the more government will be forced to take notice.

It has also been opined by Efroymson (2006) that "media coverage of an issue will also encourage the public to realize that the issue being reported is important. Therefore, to keep an issue in people's minds, we have to keep them in the news" (p.6).

Drawing from the foregoing therefore it becomes quite imperative to understand that reporting repeated cases of oil thefts in the Niger Delta region does not fall within the purview of media advocacy but using those cases to push for strong laws and the enforcement of existing laws is the premise upon which media advocacy rests.

This view had initially been echoed by Wallack (1993) who notes that "the mass media's ability to set the public agenda and amplify and lend legitimacy to the voices of our nation's political debates render them essential participants in social change of any kind" (p.2). 
In contemporary scenarios, media advocacy is being used increasingly as a method of achieving maximum media publicity to add to the changing climate of opinion on issues of socio-political importance. The publicity so far achieved, raises the profile and status of the issues both nationally and internationally.

In a study - A most potent weapon: Three cases of media advocacy- by the medical profession in the fight for tobacco control Woollard (2000) found that "one strong headline in a newspaper is far more effective than a very detailed 500 page outside the media submission that took months of painstaking work to produce (p. 252).

Evans and Ulasevich(2005) streamline media advocacy as encompassing setting the agenda, shaping the debate and advancing a policy approach. The presupposition however is that media advocacy is vital for social change and that newspapers are vital to the process of social change.

Scholars have also found a close correlation between media coverage of issues and the importance the public accords to such issues. In other words, when the mass media emphasise a topic, the audience/public receiving the message will consider the topic to be important.

Lending credence to this, Walgrave and Aeslt (2006) note that in advanced industrial democracies, the mass media are part of politics and they are the market place/ arena in which political ideas and proposals are launched, tested, scrutinized and contested" (p.100). The presupposition here is intrinsically linked to the notions of agenda setting.

Theoretical assumptions also show these to converge significantly with many other paradigms such as framing and gate-keeping. This however could be likened to what Severin and Tankard (2001) described as a "camera organizing ideas for news content that supplies a context and suggests what the issue is through the use of selection, emphasis, exclusion and elaboration"(p.106).

The summation is that there is a structural convergence between advocacy, agenda setting and framing. The underlying factor here is the ability to propagate a predominant viewpoint. The foregoing synthesis however lends corroboration to the fact that theoretical assumptions about media influences hold plausibility for the ability of the media to covertly mould public opinion in a free market place of ideas. This is the beauty of media advocacy as aptly epitomized in this paradigm shift.

\section{The methodology}

This study, by its very nature and design lends itself to content analysis which has been aptly defined as a research methodology that examines words or phrases within a wide range of texts.

Laldas and Bashkaran (2008) see content analysis as "the scientific study of communication content with reference to the meanings, contexts and intentions contained in messages" (p. 173). As an unobtrusive method of research, its dynamics will no doubt facilitate a study of the manifest content of the mass media as epitomized here by the Nigerian press. In descriptive terms, therefore, the manifest content of two Nigerian newspapers and one magazine were studied within the content analytical framework of objectivity and generalizability.

The two newspapers - The Guardian and This Day were purposively selected based on the fact that both are foremost national dailies. More so, they command widespread readership as outlined in the records of the Audit Bureau of Circulation $(\mathrm{ABC})$. Subliminal considerations were further given to the fact that since the proprietors of the two newspapers are from the Niger Delta region, the setting of the study, the collective problem of the region may invariably be brought to bear on the editorial content of these newspapers.

For the magazine, Tell was purposively selected based on its ideological posture and national spread. So far, the magazine is presumed to be rated the most vocal and outstanding in the print media landscape of Nigeria.

The period of study however fell within the third quarter of 2013 owing to the fact that this period was marked by the aftermath of the drastic drop in the federation account occasioned by the drop in oil revenue. This drop no doubt was attributed to the menace of oil thieves in the Niger Delta region.

The population of the study comprised 92 issues of the newspapers studied as spread across ninety two days ( $1^{\text {st }}$ July $30^{\text {th }}$ September,2013) while that of the magazine stood at twelve (12) issues being a weekly print. Based on this, the sample size was drawn based on a weekly study plan. To this end, twelve (12) issues each of the newspapers were selected and studied while twelve (12) issues of the magazine were selected and studied. Cumulatively, thirty six issues of the newspapers and magazines spread across the twelve weeks of the study period were selected and studied using a constructed calendar as shown in fig. 1. 


\section{CONSTRUCTED STUDY CALENDAR 2013}

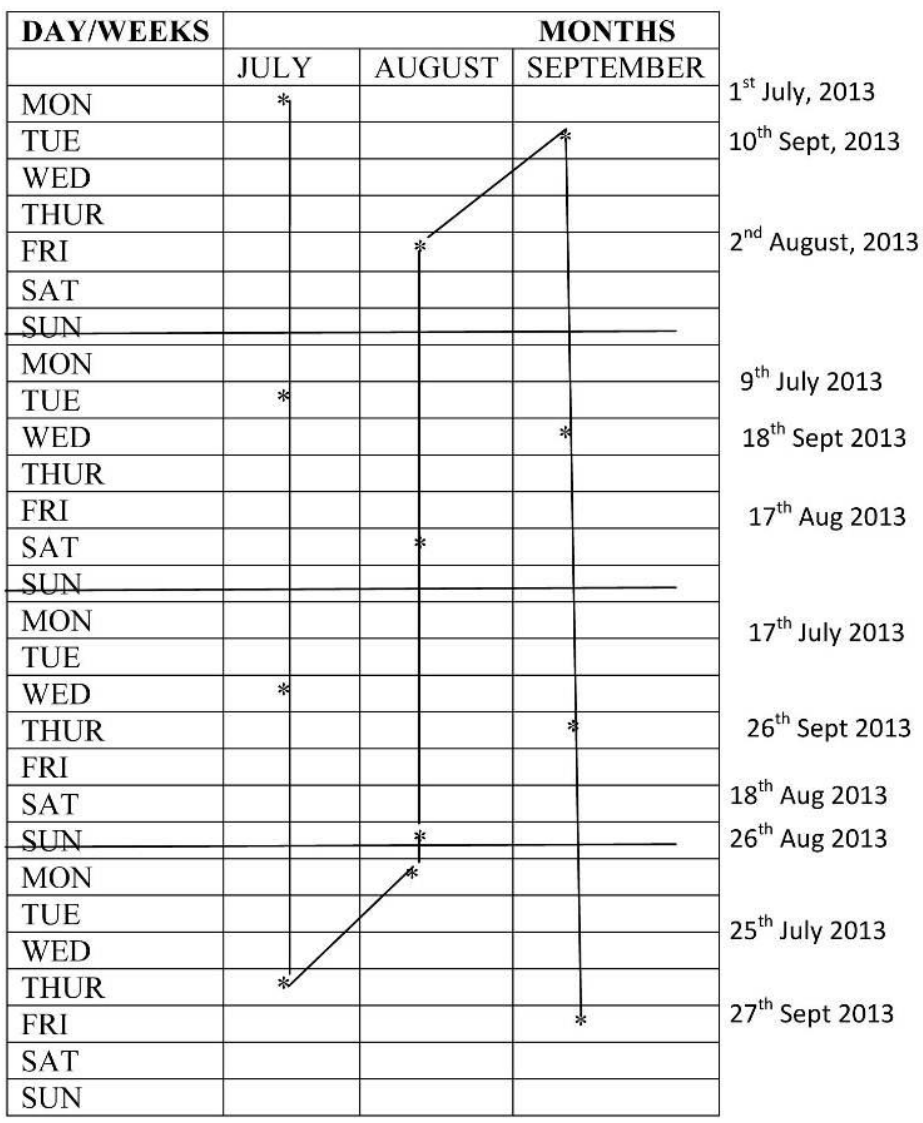

Figure 1. Constructed study calendar

NOTE: The essence here is that the constructed calendar approach demands the construction of a graph that will have twelve columns and twenty-eight rows. The columns are for the months while the rows are for the frequency of days in a month. To this end, therefore, the newspaper editions of $1^{\text {st }}, 9^{\text {th }}, 17^{\text {th }}$ and $25^{\text {th }} \mathrm{July}, 2^{\text {nd }}, 17^{\text {th }}, 18^{\text {th }}$ and $26^{\text {th }}$ August and $10^{\text {th }}, 18^{\text {th }}, 26^{\text {th }}$ and $27^{\text {th }}$ September, 2013 were selected and studied. For the magazine, the issues were selected across the twelve weeks. This was considered sizeable and representative.

The procedure for analysis consisted of an operationalization of the subject matter. To this end, the subject matter-oil theft- was defined as "any form of interpretative writing representing the corporate and allied opinion of a newspaper/magazine which calls attention to the oil theft menace and recommends ways of curbing the ugly trend"

By deduction, therefore, the editorial pages and the feature columns formed the principal units of this analysis. Advertorials in the form of public service announcements (PSA) by the newspapers and magazines were also incorporated and studied.

Measurement was carried out for news content that fell within the purview of the foregoing definition. News space was measured in column centimeter and this formed the basis for quantitative analysis.

Based on the foregoing, coding of content into categories was made along the lines of editorial, features and advertorial since they naturally lend themselves to advocacy.

To ensure reliability and researcher non-bias, a professional coder was employed to assist in the coding. A total of 278 were categorized. Based on the categorization, the coders agreed on 202 categories and disagreed on 76 categories. Differences in coding were correlated using Holsti (1968) formula:

Where; 
C1.2 $=$ Number of category assignment agreed on

$\mathrm{C} 1+\mathrm{C} 2=$ Total number of category assignments made by both coders

$\mathrm{r}=$ correlation

$=2(202)$

$=(278+278)$

$=2 \times 202$

556

$=404$

556

$=0.73$

The computation shows a high correlation which no doubt holds validation for the coding categories.

\section{Data presentation}

Table 1. Content distribution in The Guardian

\begin{tabular}{lll}
\hline Content & Allocation of space in column centimeters & Space in percentage \\
\hline Straight news & 179,484 & 17.00 \\
Editorial & 4,836 & .48 \\
Features & 136,500 & 13.69 \\
Advertorials & 629,436 & 63.10 \\
Sports & 47,244 & 4.73 \\
Total & 997,500 & 100 \\
\hline
\end{tabular}

With a conventional news space distribution, focus however was given to the allocation of news space to the subject matter in the light of public information, frequency and advocacy.

Table 2. Content on oil theft in The Guardian

\begin{tabular}{lll}
\hline Content & Allocation of space in column centimeters & Space in percentage \\
\hline Straight news & 12,850 & 1.35 \\
Editorial & 0 & 0 \\
Features & 37,500 & 3.95 \\
Advertorials & 0 & 0 \\
\hline
\end{tabular}

$$
\mathrm{N}=950,256 \text { col.cms }
$$

Content was devoted to straight news and features on the subject matter

Table 3. Content distribution in This Day

\begin{tabular}{lll}
\hline Content & Allocation of space in column centimeters & Space in percentage \\
\hline Straight news & 255,000 & 39.94 \\
Editorial & 7,800 & 1.23 \\
Features & 113,400 & 17.76 \\
Advertorials & 216,600 & 33.93 \\
Sports & 45,600 & 7.14 \\
Total & 638,400 & 100
\end{tabular}

Preponderance of news space for straight news was closely followed by that for advertorials

Table 4. Content on oil theft in This Day

\begin{tabular}{lll}
\hline Content & Allocation of space in column centimeters & Space in percentage \\
\hline Straight news & 11,400 & 1.92 \\
Editorial & 0 & 0 \\
Features & 45,600 & 7.69 \\
Advertorials & 0 & 0 \\
\hline \multicolumn{2}{c}{$\mathrm{N}=592,800$}
\end{tabular}

News space for features in contradistinction to straight news was quite remarkable 
Table 5. Content distribution in Tell

\begin{tabular}{lll}
\hline Content & Allocation of space in column centimeters & Space in percentage \\
\hline Straight news & 112,320 & 31.25 \\
Advertorials & 70,200 & 19.53 \\
Features & 134,784 & 37.50 \\
Letters & 42,120 & 11.72 \\
Total & 359,424 & 100 \\
\hline
\end{tabular}

Content was predominantly devoted to features, a genre of interpretative reporting. This is not out of place since interpretative reporting is the major forte of magazines.

Table 6. Content on oil theft in Tell

\begin{tabular}{lll}
\hline Content & Allocation of space in column centimeters & Space in percentage \\
\hline Straight news & 0 & 0 \\
Advertorials & 0 & 0 \\
Features & 27,900 & 7.76 \\
Letters & 2,400 & 0.66 \\
\hline
\end{tabular}

As would be expected, content was devoted more to features in contradistinction to other categories.

Table 7. Frequency of coverage

\begin{tabular}{lll}
\hline Newspapers/magazine & Number of weeks & Frequency of reportage \\
\hline The Guardian & 12 & 4 \\
This Day & 12 & 2 \\
Tell & 12 & 1 \\
Total & 36 & 7 \\
\hline
\end{tabular}

The frequency of coverage given to oil theft by the newspaper and magazine studied was $19 \%$.

Table 8. Advocacy index

\begin{tabular}{|c|c|c|c|c|}
\hline Categories & The Guardian (col.cms) & This Day (col. cms) & Tell (col.cms) & Total (col.cms) \\
\hline Editorial & 0 & 0 & 0 & 0 \\
\hline Features & 37,500 & 45,600 & 27,900 & 111,000 \\
\hline Advertorial & 0 & 0 & 0 & 0 \\
\hline Total & 37,500 & 45,600 & 27,900 & 111,000 \\
\hline
\end{tabular}

The presupposition however is that editorials, features and advertorials lend themselves to advocacy. Table 8 therefore shows that out of a cumulative space of 1,313,556 col.cms, the papers studied devoted 111,000 col.cms to advocacy in the form of features on the subject matter. This represents eight $(8 \%)$ percent of the total news space.

\section{Discussion}

A synthesis of the data as observed from the tables show that the coverage given to the menace of oil theft in the Niger Delta region was not sufficient to draw attention to the issue and hence cause it to become topical in the arena of public discourse. A break down shows that for The Guardian, the straight news coverage on the subject matter was $1.35 \%$ while features stood at $3.95 \%$. Incidentally, content was not devoted to editorial and advertorial.

For This Day, straight news content on the subject matter was $1.92 \%$ while features stood at $8 \%$. Content was also not devoted to editorial and advertorial on the subject matter. Tell magazine on the other hand, devoted $7.76 \%$ of its news space on features to the subject matter with nothing on advertorial and editorial.

The inference however is that the coverage as espoused above may not qualify for adequate when viewed in a continuum. It is however expected that since the media set the agenda for public discussion, the reportage on oil theft should have been such that focus and attention will be drawn to the subject matter with a view to sensitizing the public on the inherent dangers of oil theft.

Going by Noelle- Neumann's (1973) typology of cumulation, consonance and salience as key components of the agenda setting function of the press, it will be inferred that the cumulative coverage of the subject matter by the newspapers and magazines studied was abysmal. In terms of consonance, the inference showed a negative pattern bearing in mind the fact that less than $2 \%$ was devoted to straight news reportage on the subject matter by the respective newspapers/magazine studied. The same pattern also played out in the features with a lateral $0 \%$ across the editorial and 
advertorial spectrum. An extrapolation of this synthesis showed that the newspapers/magazine studied did not accord salience to the subject matter going by the shrift reportage it received.

In terms of advocacy geared towards proffering solutions on how to stem the tide of oil theft in the Niger Delta region, the newspapers/magazine studied did not devote much space to advocacy as shown on table 8. More unfortunately so, three advocacy tools of editorial and advertorial were not utilized by the papers studied. This is a typical case of the media shirking and failing in their cardinal responsibility of sensitizing the public on issues of general concern. Since oil is the mainstay of the Nigerian economy, activities that threaten its unhindered exploration should be treated as prime issues that threaten the wellbeing of the citizenry by the mass media. In this regard, the media are expected to focus attention on such issues and drive for action on how to curb the negative trend. As deduced from the data, the newspapers/magazine studied did not fare well in the foregoing context going by the thrust of figure 2 .

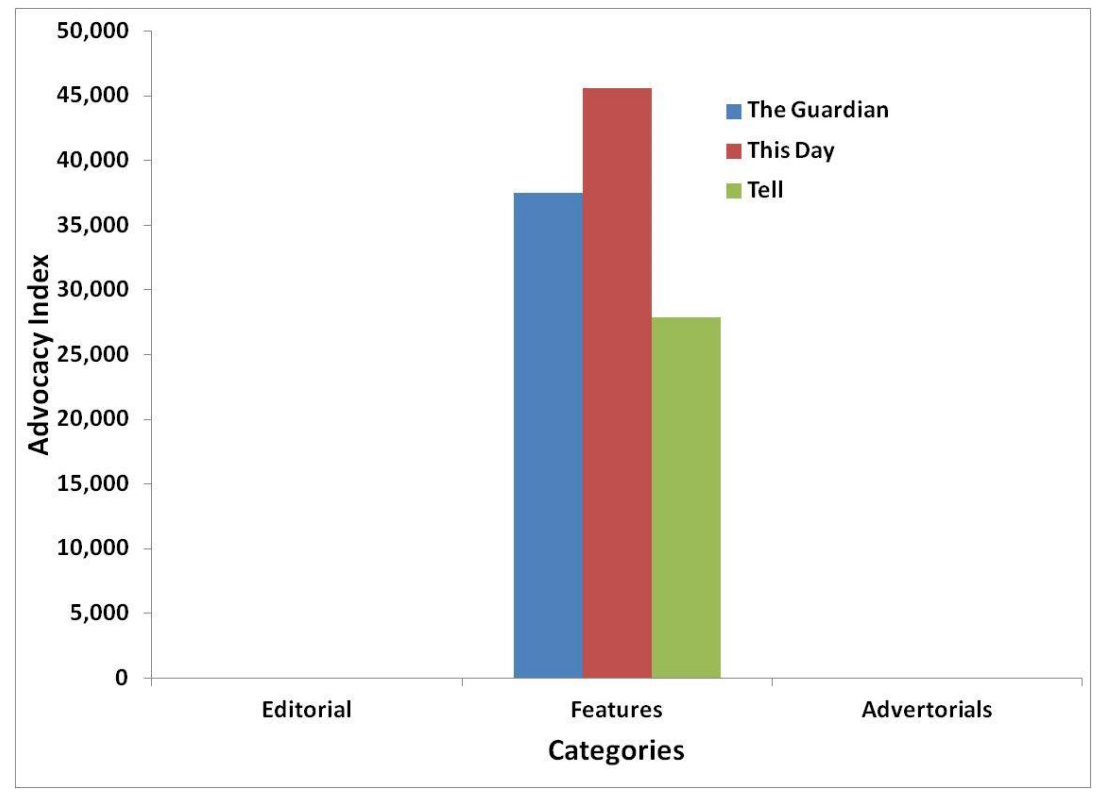

Figure 2. Bar chart showing levels of advocacy by the newspapers/magazine

The frequency of coverage on the subject matter was equally not commendable. This is so because there was no concerted effort by the newspapers/magazine studied to ensure consistency and perseverance through an increase in the number of days the issue was reported as against the period of study. This is graphically represented in fig. 3 .

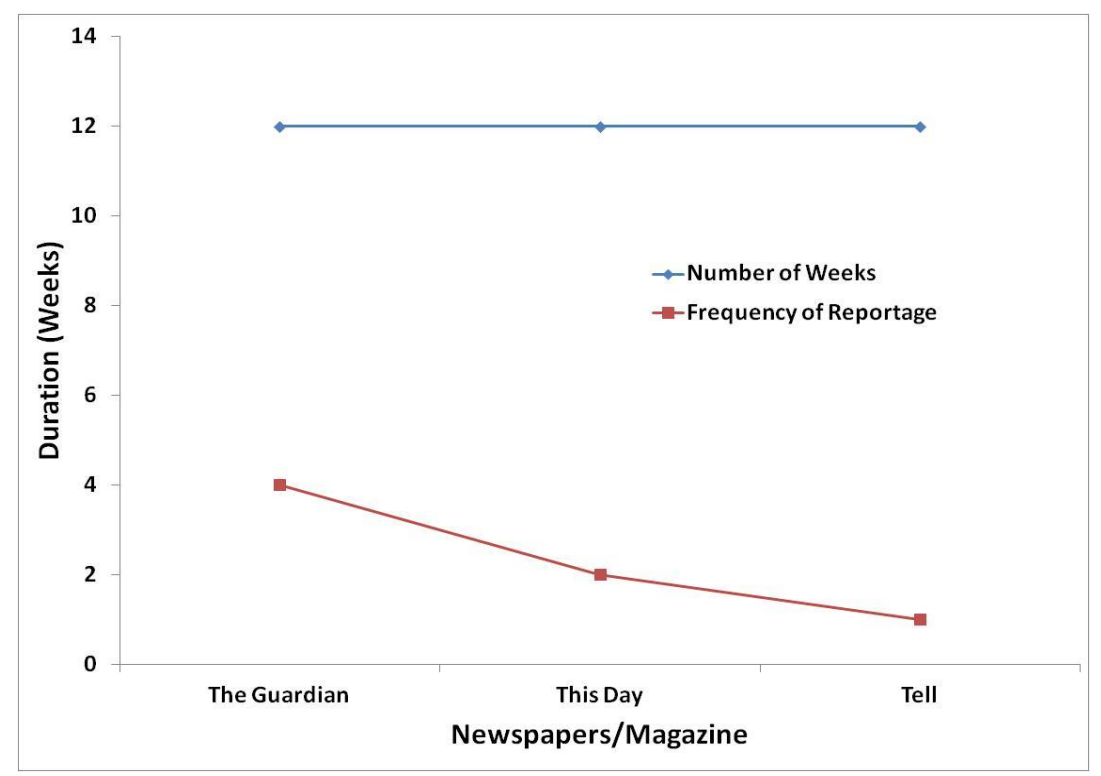

Figure 3. Graph showing the frequency of reportage 
A summation of the findings showed that the reportage given to the subject matter by the newspapers/magazine studied was not sufficient to ensure a platform for public enlightenment on the dynamics of oil theft and its attendant implications on the socio-economic wellbeing of the Nigerian nation. This has become worrisome bearing in mind the fact that it is a great aberration when the mass media's disposition on an issue of topical interest seems to be that of disinterest.

\section{Recommendations}

1) There should be concerted efforts by Nigerian newspapers and magazines to focus content on issues of public importance with a view to sensitizing the public on the implications of such issues on the socio-economic milieu. This in turn will stimulate public discourse which inadvertently will generate opinion on the way forward.

2) There is need for Nigerian newspapers and magazines to intensify advocacy on issues of public concern by using editorials, advertorials and features to enlighten policy makers on the need for proactive policies that will be geared towards creating an enabling environment for the emergence of an egalitarian society.

3) Issues of great concern require consistency and perseverance in reportage. To this end, there should be a renewed zeal by Nigerian newspapers and magazines to steadily and consistently focus on issues of public concern by way of frequently devoting content on those issues over a long period so as to adequately sensitize awareness.

4) There should be a wakeup call on Nigerian newspapers and magazines not to abdicate their corporate social responsibility of carrying out surveillance functions by focusing content on how to correct the ills in the society. To this end, there may be need to impose a statutory benchmark of devoting at least $20 \%$ of their total newspaper space to socio-economic and socio-political issues.

\section{References}

Ameh, J. (2013, July 17). Nigeria loses 400,000 barrels of oil daily. The Punch.

Evans, D., \& Ulasevich (2005). News media tracking of tobacco control: A review of sampling methodologies. Journal of health communication international perspectives, 10(5), 403-417.

Dominick, J. (2011). The dynamics of mass communication: Media in transition. Athens: McGraw-Hill International edition.

Efroymson, D. (2006). Using media and research for advocacy: Low cost ways to increase success. London: Health Binge.

Hasan, S. (2013). Mass communication: Principles and concepts. New Delhi: CBS publishers of Distribution Pvt Ltd.

Ibru, G. (2013). Shortfall in allocation to the three tiers of government. Retrieved from (http://www.osundefender.org/?p=125430).

Laldas, D., \& Bashkaran, V. (2008). Research methods for social work. New York: Rawat.

McQuail, D. (2012). McQuail's mass communication theory (6 ${ }^{\text {th }}$ edition). Thousand Oaks, califorms: SAGE publications.

Noelle-Neumann, E. (1973). Return to the concept of powerful mass media. Studies of broadcasting, 9, 67-112.

Rodman, G. (2012). Mass media in changing world: History industry \& controversy. New York: McGraw-Hill international edition.

Severin, W., \& Tankard, J. (2001). Communication theories origins, methods and uses in the mass media. London: Longman.

Walgrave, S., \& Aeslt, P. (2006). The contingency of the mass media's political agenda setting power: Toward a preliminary theory. Journal of communication, 56, 88-109. http://dx.doi.org/10.1111/j.1460-2466.2006.00005.x

Wallack, L. (1993). Media advocacy and public health: Power for prevention. London: SAGE.

Wallack, L. (1999). News for change: An advocate's guide to working with the media. London: Sage publications.

Woollard, K. (2000) Lobbying, advocacy and use of the mass media for tobacco control. London: Springer-vertag Limited.

World Bank. (2013). Reports. Retrieved from (www.worldbank.org/en/country/nigeria/overview).

\section{(cc) EY}

This work is licensed under a Creative Commons Attribution 3.0 License. 